\title{
LABOR AND THE ANTITRUST LAWS- A PRELIMINARY ANALYSIS
}

\section{Archibald Cox $\dagger$}

Are labor unions monopolies? Is there a conflict between the policy of encouraging unionization and collective bargaining and the older antitrust laws? Should the exemption from the antitrust laws which unions enjoy be curtailed or abolished? The importance of these questions is obvious, and one has only to follow the daily press and popular magazines to realize their widespread interest. Much of the support for legislation subjecting unions to the antitrust laws doubtless stems from organized anti-unionism, but too many friends of labor are concerned by some aspects of the problem to condemn these questions through guilt by association.

The Attorney General's National Committee To Study the Antitrust Laws wisely might have avoided discussing the relationship between antitrust policy and labor unions and collective bargaining on the ground that the topic was severable and the Committee lacked special competence in labor-management relations. ${ }^{1}$ One would have supposed, however, that if the Committee did take up the problem, it would deal with the fundamental questions, for the Committee's goal was "a thoughtful and comprehensive study of our antitrust laws" which would "provide an important instrument to prepare the way for modernizing and strengthening our laws to preserve American free enterprise against monopoly and unfair competition." 2

Had the Committee undertaken this task, it might have made a major contribution to the development of public policy. The real issues are often obscured by the uninformed (or carefully contrived) generalities uttered by lobbyists and publicists. ${ }^{3}$ Although its conclusions would not have gone unchallenged, a report which commanded

$\dagger$ Professor of Law, Harvard University. A.B., 1934, LI.B., 1937, Harvard University.

1. Very few members of the large committee are known for their work in the field of labor relations. Charles B. Rugg, Charles Q. Gregory and Sumner H. Slichter are perhaps the most notable exceptions. Clinton S. Golden was a member but took no part in the deliberations.

2. Report of the Atrorney General's National Committee To Study the ANTITRUST LAwS iv (1955) (hereinafter cited as REPORT), quoting announcements of the President and Attorney General at the time the Committee was established.

3. White, Should Unions Have Monopoly Power?, Reader's Digest, Aug. 1955, p. 33 illustrates much of the public discussion. 
respect for its fair-minded, thorough and candid discussion of the issues might have swept aside the balderdash, focused attention on the serious problems, and pointed the way toward relieving the gaps and uncertainties in our factual knowledge.

But in this field, the Committee preferred details to basic issues. Perhaps the other approach was closed by the folklore of politics. Confining the inquiry to ". . . those union activities, not directed at such established union ends [as Congress recognized in the $\mathrm{Na}$ tional Labor Relations Act], but instead at direct restraints on commercial competition," "4 the Committee postulated the belief that

". . . union actions aimed at directly fixing the kind or amount of products which may be used, produced or sold, their market price, the geographical area in which they may be used, produced or sold, or the number of firms which may engage in their production or distribution are contrary to antitrust policy." 5

From this premise the Committee proceeded through a rather debatable analysis of court decisions to the conclusion that

". . . to the extent that such commercial restraints not effectively curbed by either antitrust or Labor-Management Relations Act exist, then we recommend appropriate legislation to prohibit these union efforts at outright market control." 8

The conclusion is sound enough if the premise is sound, if means of dealing with such restraints can be devised which will not seriously interfere with desirable collective bargaining, and if the abuses exist on a scale which justifies running any unavoidable risks of interference. Perhaps the conditions are satisfied, but the Report supplies scant guidance beyond one interesting and significant suggestion. The recommended legislation would ". . . cover only specific union activities which have as their direct object direct control of the market . . . ." ? By "object" the Committee ". . . means only the immediate concession demanded from an employer as a condition precedent to halting coercive action against him." s I take this to signify that a union would be prohibited from striking to compel an employer to maintain a prescribed schedule of prices, to confine his operations to a limited geographical area or to patronize a limited group of suppliers, but that demands phrased in the conventional terms of wages, hours and condi-

4. REPORT at 294.

5. Ibid.

6. $I d$. at 304 .

7. Ibid.

8. Id. at 304-05. 
tions of employment could be pressed legitimately even though their practical effect was to reduce competition in the sale of the employer's product. The merits of the suggestion are discussed below.

Like the Report, this article offers no answers to the fundamental issues raised in the opening paragraph. It essays the hesitant first step of an elementary analysis of the relation between union organization, collective bargaining and our traditional attachment for enforced competition. Beyond this, I have ventured to state a few conclusions on points which seem too plain for further argument and to suggest some of the factors to be considered in weighing the closer questions.

\section{Monopoly in the Labor Market}

The purpose and effect of every labor organization is to eliminate competition in the labor market. Chief Justice Taft's classic statement observed:

"[Labor unions] were organized out of the necessity of the situation. A single employee was helpless in dealing with an employer. He was dependent ordinarily on his daily wage for the maintenance of himself and family. If the employer refused to pay him the wages that he thought fair, he was nevertheless unable to leave the employ and to resist arbitrary and unfair treatment. Union was essential to give laborers an opportunity to deal in equality with their employer." 9

Each bricklayer's local seeks to control the supply of bricklayers' services available to contractors within its geographical jurisdiction. United Steelworkers of America controls the supply of labor available to United States Steel Corporation. In this sense every union is an avowed monopolist.

If there was ever doubt, the Clayton Act made it plain that the mere formation of a labor union is not an unlawful combination in restraint of trade or commerce. ${ }^{10}$ The National Labor Relations Act goes farther and declares a national policy of protecting the growth of labor unions and the use of the employees' collective (i.e., monopoly) power in negotiating wages, hours and other conditions of employment. ${ }^{11}$ No one seriously suggests that antitrust policy should be concerned with the labor market per se. Where a union controls job

9. American Steel Foundries v. Tri-City Central Trades Council, 257 U.S. 184, 209 (1921).

10. Clayton Act $\$ 6,38$ STAT. 731 (1914), 15 U.S.C. $\S 17$ (1952); id. §20, 38 STAT. 738 (1914), 29 U.S.C. \$ 52 (1952).

11. National Labor Relations Act, 49 Stat. 449 (1935), as amended, LaborManagement Relations Act, 1947, 61 Stat. 136, 29 U.S.C. §141 (1952). 
opportunities, it may abuse its power by limiting access to the trade, arbitrary discrimination, denials of individual liberty or unwarranted discipline; but these are problems primarily affecting labor-management relations or internal union affairs. They have little to do with the purpose of the antitrust laws-". . . the prevention of restraints to free competition in business and commercial transactions which tended to restrict production, raise prices or otherwise control the market to the detriment of purchasers or consumers of goods and services. " 12

A union's use of its monopoly power to influence the price paid for labor by several employers may affect competition in the product market in which they sell their goods and services. Complete control over the supply of labor. may amount to power to cut off supplies essential to the public health or safety. Perhaps antitrust policy should be concerned with these indirect results and their cause. Laying such cases aside for later discussion, however, we may take it as a premise that the antitrust laws are not concerned with competition among laborers or with bargains over the price or supply of labor-its compensation or hours of service or the selection and tenure of employees.

\section{Strikes, Boycotrs ANd Picketing}

Every successful strike or boycott curtails the flow of goods or services into the market in which the employer sells his product. This is true regardless of the union's objective or the effect of the employer's yielding to its demands. The degree of restraint upon competition among employers varies greatly, however, depending upon the industry involved. Where the union has power to strike an entire industry, the supply of goods may be cut off entirely, e.g., by a coal strike. Where the market is divided among large suppliers, a strike against one concern might have an important effect upon prices even though the union's demands related to union security, seniority, arbitration or some other non-economic issue. In most cases, strikes probably affect too small a part of the supply of goods for too short a period to have a measurable effect upon prices. In a factual sense, however, there is a restraint on interstate commerce whenever a strike or boycott curtails operations in a plant whose ultimate markets are out-of-state.

In another sense too, strikes, boycotts and picketing impose restraints on competition. A combination of business firms which attempts to dictate the terms on which a trader may have access to the market constitutes a per se violation of the Sherman Act without re-

12. Apex Hosiery Co. v. Leader, 310 U.S. 469, 493 (1940). 
gard to its ultimate purpose or effect. ${ }^{13}$ This is exactly the purpose of every combination of employees engaged in primary or secondary activities in the course of a labor dispute.

In the past, it was these characteristics of strikes and boycotts that made the Sherman Act an instrument for thwarting unionization. Perhaps there is no real reason to fear the return of the worst of those abuses; yet the past explains labor's intense hostility towards the antitrust laws-a factor which must be taken into account in any realistic discussion of their revision-and it also reveals pitfalls of legal analysis.

\section{Early Sherman Act Cases}

Although newspaper editorials decried the excessive power of labor unions even in the 1880 's , $^{14}$ the only demonstrable purpose of the Sherman Act was to protect consumers against rising prices, limitations on production or the deterioration of quality, by forcing businessmen to compete with one another. But during the congressional debates, an amendment exempting labor unions was offered and defeated. ${ }^{15}$ The draftsmen, despairing of finding specific words to carry out their aim, wrote section 1's sweeping proscription of: "Every contract, combination . . . or conspiracy, in restraint of trade or commerce among the several States . . ." with the announced intention of leaving it to the courts to make specific applications. ${ }^{16}$

The development of the Sherman Act in application to labor unions is discernible from a few main steps. The generality of section 1 made the act a convenient weapon for government officials anxious to stop strikes which they thought threatened the public welfare. It was first invoked by a United States Attorney during a general strike in New Orleans. The district judge ruled:

13. Fashion Originators Guild v. FTC, 312 U.S. 457 (1941); Eastern States Retail Lumber Dealers' Ass'n v. United States, 234 U.S. 600 (1914); REPORT at 133.

14. In 1885, the New York Sun reported: "Five men in this country control the chief interests of five hundred thousand workingmen, and can at any moment take the means of livelihood from two and a half millions of souls. . . They can stay the nimble touch of almost every telegraph operator; can shut up most of the mills and factories, and can disable the railroads. . . They can array labor against capital, putting labor on the offensive or the defensive, for quiet and stubborn selfprotection, or for angry, organized assault, as they will." See Perdanan, HISTORY of Trade Unionism in the United States 88-89 (1922).

15. See Loewe v. Lawlor, 208 U.S. 274, 301 (1908); United States v. Debs, 64 Fed. 724, 747 (C.C.N.D. I11. 1894); United States v. Workingmen's Amalgamated Council of New Orleans, 54 Fed. 994,996 (C.C.E.D. La. 1893). Careful analysis of the history of antitrust bills casts doubt on the significance the courts attributed to the action. See Berman, Labor AND tre SHERman ACT (1930); Boudin, The Sherman Act and Labor Disputes, 39 Colum. L. Rev. 1283, 1285-93 (1939).

16. 21 Cong. Rec. 2460,3148 (1890). 
"The evil, as well as the unlawfulness, of the act of the defendants, consists in this: that, until certain demands of theirs were complied with, they endeavored to prevent, and did prevent, everybody from moving the commerce of the country." 17

A few years later the Attorney General pitched part of his legal argument on the statute in defending the injunction against Eugene Debs and other leaders of the Pullman strike of $1894 .^{18}$ At first only the Government could secure an injunction, but employers had standing to sue for treble damages, ${ }^{19}$ and after 1914 , the way was opened to equitable relief in private actions. ${ }^{20}$ In 1932, the Norris-LaGuardia Act cut off any right to an injunction against peaceful activities in cases arising out of labor disputes, ${ }^{21}$ but it was not until nine years later that court decisions gave unions wide immunity from the antitrust laws by extending the policy of the Norris-LaGuardia Act to criminal prosecutions and actions for damages. ${ }^{22}$

The cases decided during the intervening half century fall into three groups. One set revolved about the question: what is a "restraint of trade or commerce among the several States"? The concepts of interstate commerce which prevailed up to 1937 curtailed the application of the Sherman Act in strikes at mines, mills or factories, ${ }^{23}$ but the revolution in constitutional interpretation heralded by $N L R B$ v. Jones \& Laughlin Steel Corp., ${ }^{24}$ coupled with the precedents holding that the reach of the Sherman Act is as broad as the power of Congress, makes it plain that the limitation is no longer significant.

We may also lay aside the cases interpreting sections 6 and 20 of the Clayton Act. Section 6 proved empty because inapplicable to concerted activities in organization and collective bargaining. ${ }^{25}$ Section 20 afforded immunity to the immediate employees of an employer when engaged in peaceful and lawful activities during a dispute concerning terms or conditions of employment, but the exemption did not

17. United States v. Workingmen's Amalgamated Council of New Orleans, 54 Fed. 994, 1000 (C.C.E.D. La. 1893).

18. The circuit court based its decision on the Sherman Act. United States v. Debs, 64 Fed. 724 (C.C.N.D. Ill. 1894), aff'd on other grounds, 158 U.S. 564 (1895).

19. Sherman Act $\$ 7,26$ Stat. 210 (1890), as amended, 15 U.S.C. $\$ 15$ (1952).

20. Clayton Act $\S 16,38$ Stat. 737 (1914), 15 U.S.C. $\S 26$ (1952).

21. 47 Stat. 70 (1932), 29 U.S.C. \$ 101 (1952).

22. United States v. American Federation of Musicians, 318 U.S. 741 (1943); United States v. Building \& Construction Trades Council, 313 U.S. 539 (1941); United States v. Hutcheson, 312 U.S. 219 (1941).

23. Local 66, United Leather Workers v. Herkert \& Meisel Trunk Co., 265 U.S. 457 (1924); Dist. 21, United Mine Workers v. Coronado Coal Co., 259 U.S. 344 (1922).

24. 301 U.S. 1 (1937).

25. Duplex Printing Press Co. v. Deering, 254 U.S. 443, 469 (1921). 
extend to secondary activities or to organizational strikes or to picketing by an outside union. ${ }^{26}$

The third major issue was: what kinds of union activity constitute a forbidden "contract, combination . . . or conspiracy in restraint of trade or commerce"? The courts' response was unavoidably affected by the judges' interpretations of section 1 in business cases.

(a) One reading was quite literal. In United States $v$. TransMissouri Freight Ass'n, the majority held:

"When, therefore, the body of an act pronounces as illegal every contract or combination in restraint of trade or commerce . . all contracts are included in such language, and no exception or limitation can be added without placing in the act that which has been omitted by Congress." 27

(b) An alternative approach was to look to common-law concepts of restraint of trade, thereby giving the Sherman Act the effect of rendering unlawful in an affirmative or positive sense those contracts which were condemned by the common law in the sense that they were unenforceable. According to one view of the common law, restraints ancillary to a normal business transaction were unenforceable, if not reasonably necessary to protect the interest involved in the principal transaction, while non-ancillary restraints (such as price-fixing or the allocation of territory among competing firms) were against public policy without further inquiry. Its classic exposition is Circuit Judge Taft's opinion in United States v. Addyston Pipe \& Steel Co. ${ }^{28}$

(c) Standard Oil Co. v. United States ${ }^{2 \theta}$ established the doctrine which gained acceptance in business cases. The Court concluded that Congress had proscribed ". . . all contracts or actions which were unreasonably restrictive of competitive conditions. . . ." 30 because of either the character of the contract or some surrounding circumstances which gave rise to the inference that they tended to bring about the enhancement of prices and related evils which were considered to be against public policy. Although this "rule of reason" nominally applied to all restraints, later cases created the so-called "per se offenses" by conclusively presuming certain types of restraint, such as price-fixing and group boycotts, to be unreasonable. ${ }^{31}$ Thus qualified

26. Id. at 469-71. See also Alco-Zander Co. v. Amalgamated Clothing Workers, 35 F.2d 203 (E.D. Pa. 1929).

27. 166 U.S. 290, 328 (1897).

28. 85 Fed. 271 (6th Cir. 1898).

29. 221 U.S. 1 (1911).

30. $I d$. at 58 .

31. E.g., Fashion Originators Guild v. FTC, 312 U.S. 457 (1941); United States v. Trenton Potteries Co., 273 U.S. 392 (1927). 
the rule of reason seems quite similar to the approach outlined by Circuit Judge Taft.

The literal approach had marked influence on the early opinions applying section 1 to union activities. In the Danbury Hatters case, ${ }^{32}$ for example, the union had organized most hat manufacturers, but not the plaintiff. In an effort to organize the plaintiff, the union not only called a strike at its factory but also arranged a boycott of its hats and of any dealer who might sell them. AFL supported the boycott by blacklisting the plaintiff and making public statements in the American Federationist. After a bitter struggle in which plaintiff suffered heavy losses, he brought an action for damages. The Supreme Court held that the boycott violated the Sherman Act because:

“. . [The act] prohibits any combination whatever to secure action which essentially obstructs the free flow of commerce between the States, or restricts, in that regard, the liberty of a trader to engage in business. ${ }^{33}$

Under this ruling there was no need to prove an effect on competition nor to inquire into the reasonableness of the defendant's conduct. Any strike which obstructed an employer's business was unlawful if the business had the requisite effect on interstate commerce.

The establishment of a "rule of reason" for business concerns is scarcely reflected in opinions applying the antitrust laws to labor disputes. Perhaps the explanation is that after the passage of the Clayton Act many of the leading cases involved secondary boycotts which are conceptually similar to commercial practices treated as per se offenses. $^{34}$ I think it more likely, however, that the courts did not consider the rule of reason pertinent except where the issue was the legality of a restraint on competition. Circuit Judge Woods laid the foundation for this approach in United States $v$. Debs ${ }^{35}$ before the rule of reason was formulated. Conceding that the words "in restraint of trade" had a well-known common-law meaning, he argued that section 1 ". . . in so far as it is directed against contracts or combinations in the form of trusts, or in any form of a 'contractual character,'

32. Loewe v. Lawlor, 208 U.S. 274 (1908).

33. $I d$. at 275 .

34. This was the conclusion Chief Justice Hughes drew from the precedents in his dissenting opinion in Apex Hosiery Co. v. Leader, 310 U.S. 469, 521 (1940). The majority opinion asserted "that this Court has never applied the Sherman Act in any case, whether or not involving labor organizations or activities, unless the Court was of opinion that there was some form of restraint upon commercial competition in the marketing of goods or services. ..." Id. at 495. (Emphasis added.) Most commentators have questioned the accuracy of this summary of the Court's early decisions. See text at p. 264 infra. (1897).

35. 64 Fed. 724 (C.C.N.D. I1l. 1894), aff'd on other gronnds, 166 U.S. 290 
should be limited to contracts and combinations such, in their general characteristics, as the courts have declared unlawful." ${ }^{35 a} \mathrm{He}$ refused to put the same limitation on the word "conspiracy," however, on the ground that it would make the statute tautologous to conclude that only conspiracies founded upon contracts or combinations in restraint of trade were within the purview of the act. Since the opinions which postdated the Standard Oil case are less explicit, one cannot be sure whether the judges simply followed this precedent or conscientiously based their decisions on notions of policy which they deemed it unwise to explicate. In any event, the courts in labor cases commonly deemed it enough to prove a conspiracy to obstruct or prevent transportation in interstate commerce.

In later antitrust cases, in which the "rule of reason" of the Sherman Act was not applied, courts were afforded two alternative approaches. A court might hold a combination which obstructed interstate commerce unlawful whenever it was not immunized by section 20 of the Clayton Act, or else it could focus on the word "conspiracy" and use the term to formulate a judicial policy towards strikes and picketing. In either event unionization was impeded. In the Alco-Zander case, ${ }^{\mathbf{6}}$ for example, the evidence showed that Amalgamated Clothing Workers had successfully organized the New York manufacturers and established union conditions. The Philadelphia manufacturers were unorganized. They paid wages below the New York scale and hired workers under yellow dog contracts. Both groups sold clothes in the same intensely competitive markets. Because of their higher labor costs, the New York manufacturers began to lose business, to lay off workers, to talk about wage cuts, and, in some cases, to run away to non-union Philadelphia. Amalgamated could not protect its members' jobs and wage scale except by organizing the Philadelphia market. Gradual, peaceful organization was impossible, for employees were discharged as soon as they revealed their union membership. A secret drive was started, and when enough members were signed, Amalgamated called a strike. The district judge found that

". . . the primary purpose of the campaign for the unionization of the Philadelphia market was the protection of the unionized markets in other states, particularly New York, and that, while the improvement of the condition of the workers in Philadelphia may have been present as a motive, it was at best a secondary and remote one." 37

35a. Id. at 748 .

36. Alco-Zander Co. v. Amalgamated Clothing Workers, 35 F.2d 203 (E.D. Pa. 1929).

37. Id. at 205 . 
Such a strike, even though peaceful, violated the Sherman Act because

". . . it is the intent to stop production for the purpose of controlling interstate commerce and not the methods used which makes the act unlawful. . . . It can make no difference that the union proceeded to carry out its purpose by means of a series of strikes. . . ." 38

Under this decision, it is hard to see how any union could use a strike or picket line to organize new territories or even to obtain better wages from a low wage firm.

Use of the Sherman Act to formulate labor policy also characterized the only major campaign ever launched by the Government against union-imposed restraints of interstate trade or commerce. In 1937, Assistant Attorney General Arnold launched a program against what he deemed restrictive practices but gave assurance that there would be no interference with legitimate organizational techniques or collective bargaining. ${ }^{39}$ The standards promulgated by the Antitrust Division scarcely reveal how it proposed to distinguish the legitimate from the restrictive, but the cases selected for prosecution show that the Division's views on labor policy were highly influential. United States $v$. Hutcheson ${ }^{40}$ involved a strike and picketing at the site of a new brewery, resulting from the ancient jurisdictional quarrel between the millwrights and the machinists over the installation of machinery. The gist of the offense charged in another prosecution was the defendant's purpose to compel an employer to violate the National Labor Relations Act. ${ }^{41}$ Such strikes and boycotts are wasteful and unfair to both employers and employees. Cumulatively, they burden and obstruct interstate commerce. But unless we are to lump all problems affecting the flow of commerce under the antitrust laws, there is no more reason to judge the legality of strikes in Sherman Act prosecutions than to indict, under the Sherman Act, gangsters planning to rob a trucking concern or blow up an interstate train. Since the general run of labor disputes has little to do with the preservation of a competitive economy, antitrust doctrines throw scant light on the best means of resolving the conflicts of interest among employers, employees and labor unions. While the restrictive doctrines of the common law could hardly flourish today on so wide a scale as in the

38. Id. at 208.

39. ARnold, BotTlenecks of Business c. 11 (1940).

40. 312 U.S. 219 (1941). (1941).

41. United States v. Building \& Construction Trades Council, 313 U.S. 539 
nineteen-twenties, the judicial process and judge-made law contain intrinsic limitations making them unsuited to the development of labor policy. ${ }^{22}$

\section{The Apex Case ${ }^{43}$}

In 1938, the Supreme Court took steps to halt the use of the Sherman Act as a vehicle for policing strikes affecting interstate commerce. The American Federation of Hosiery Workers had sponsored a violent sitdown strike in an effort to organize a Philadelphia firm which shipped its products in interstate commerce. Not only was the production of stockings halted by violence, but the strikers who had seized the mill specifically refused to release a freight car already loaded for shipment to other states. The strikers' conduct was obviously criminal, and they might also have been sued for damages under the laws of Pennsylvania. In an effort to recover the treble damages, however, the employer brought an action under the Sherman Act and alleged that the sitdown strike was a combination or conspiracy in restraint of trade. Either the strike was too short or the firm was too small for the delay in shipments to affect market price, and there was no evidence that the Hosiery Workers were motivated by the desire to drive non-union competition from the market. Nevertheless, interstate commerce was affected within the new constitutional doctrines and, once over this hurdle, the earlier antitrust decisions seemed to support the plaintiff.

The Supreme Court held the Sherman Act inapplicable. Justice Stone, who wrote the opinion, went back to the three fundamental views concerning section 1 and adopted Circuit Judge Taft's position that section 1 makes criminal only the kind of restraint of competition which was discountenanced at common law. ${ }^{44}$ Labor cases aside, ". . . some form of restraint of commercial competition has been the sine qua non to the condemnation of contracts, combinations or conspiracies under the Sherman Act, and in general restraints upon competition have been condemned only when their purpose or effect was to raise or fix the market price." 45 After a Procrustean effort to force the labor cases into the same mold, the Justice declared that the Sherman Act did not apply to strikes or other activities of labor unions unless they affected commercial competition. Strikes may restrict the employer's power to compete in the market, but ". . . the

42. $\mathrm{My}$ reasons for this belief are stated in $\dot{\mathrm{C}} \mathrm{x}$, The Role of Law in Labor Disputes, 39 CORNELI, L.Q. 592 (1954).

43. Apex Hosiery Co. v. Leader, 310 U.S. 469 (1939).

44. See text at note 28 supra.

45. 310 U.S. at 500 . 
mere fact of such restrictions on competition does not in itself bring the parties to the agreement within the condemnation of the Sherman Act." ${ }^{48}$ The Justice concluded that the violence was irrelevant and the combination was outside the reach of section 1 because it did not “. . . have an effect upon prices in the market or otherwise deprive purchasers or consumers of the advantages which they derive from free competition." 47

The Apex decision was a great advance over earlier cases. If the Court adhered to its doctrine, the Sherman Act could no longer be used for policing strikes, boycotts and picketing according to judicial notions of unlawful labor objectives and unlawful means. It is also important to observe, however, that the case left many important questions unanswered. "Commercial competition" is not a word of art. Since the law took a still different turn before the Court could apply its new test, ${ }^{48}$ we have little guidance with respect to its meaning. The point is important because we are sometimes urged to turn the clock back to the day of the Apex case. ${ }^{49}$

Perhaps commercial competition is to be equated to competition in the product market in which the employer sells his goods. On this assumption several questions arise:

(a) Would it be a violation of section 1 of the Sherman Act for the Teamsters' Union to encourage the employees of retail outlets not to handle the products of a baker with whom the union has a dispute? The Attorney General's National Committee apparently believes that all secondary boycotts restrict commercial competition. ${ }^{50}$ Others would suppose that the problem posed purely a question of labor policy like a strike at a mine or factory.

(b) Will the Court be guided by the "kind of combination"; the purpose, motive or intent; or by the effect on commercial competition? Motivation is a slippery guide, for a man can always be found to, and in a sense does, intend any consequence which foreseeably fol-

46. Id. at 503 .

47. Id. at 501 .

48. See text at p. 264 infra.

49. See text at note 110 infra, discussing a bill approved by the House of Delegates of the American Bar Association.

50. REPORT at 302 n.194.

51. I use this awkward phrase to denote the kind of immediate restraint upon competition in the product market discussed in the next section of this paper-pricefixing agreements, embargoes on all out-of-state goods and similar restraints whose only function-judged by examining the restraint instead of psychoanalyzing the restrainer or tracing the economic consequence-is to provide employers with a sheltered market. Query whether the phrase is any help. The problem of definition here reminds one of the difficulty in defining a beautiful woman. I trust that the reader's ability to recognize one will be as good in the first case as in the second. 
lows from his conduct. Did the Machinists intend to limit commercial competition or only to spread their membership when they negotiated contracts with the St. Louis breweries requiring new machinery to be installed by contractors who had collective agreements with the Machinists' rather than the Millwrights' Union? If proof of an adverse "effect" on consumers is enough even though the union confines itself to the labor market, then the act may apply to any strike which impairs the flow of goods or services essential to the public health or safety or the national economy. It might also affect bargaining demands which have an impact on price competition or the level of production.

(c) Justice Stone's opinion contains inconsistencies that emphasize the ambiguity on the latter point. Many passages imply that there might have been a violation if the Apex strike had affected market price. $^{52}$ The Second Coronado case ${ }^{52 a}$ was described as an illustration of an illicit restraint on competition because it involved an organizational strike against a non-union operator whose low cost coal threatened the union wage scale. ${ }^{53}$ Yet a famous dictum in the Apex opinion also declared that ". . . elimination of price competition based on differences in labor standards . . has not been considered to be the kind of curtailment of price competition prohibited by the Sherman Act." 54

\section{The Hutcheson Case ${ }^{55}$}

In 1941, the doubts and problems left by the Apex opinion were swept into limbo by a series of decisions resulting from Assistant Attorney General Arnold's prosecution of labor unions. ${ }^{56}$ A majority of four Justices, later joined by others, ${ }^{57}$ ruled that the Norris-LaGuar-

52. See, e.g., 310 U.S. at 493, 501, 504, 512-13.

52a. Coronodo Coal Co. v. United Mine Workers, 268 U.S. 295 (1925).

53. Id. at 511-12. Note also the Court's statement that "we only hold now . . . that such restraints [as conspiracies to obstruct interstate transportation] are not within the Sherman Act unless they are intended to have, or in fact have, the effects on the market on which the Court relied to establish violation in the Second Coronado case." Id. at 512 .

54. Id. at 503-04.

55. United States v. Hutcheson, 312 U.S. 219 (1941).

56. The Hutcheson case was followed by a series of per curiam decisions. United States v. Building \& Construction Trades Council, 313 U.S. 539 (1941); United States v. United Brotherhood of Carpenters, 313 U.S. 539 (1941); United States v. International Hod Carriers Council, 313 U.S. 539 (1941); United States v. American Federation of Musicians, 318 U.S. 741 (1943).

57. In the Hutcheson case, the majority was composed of Justices Frankfurter, Black, Douglas and Reed. Justice Stone filed a concurring opinion applying the Apex doctrine. The Chief Justice and Justice Roberts dissented. Justice Murphy did not participate, and Justice McReynolds retired two days before the decision. Later cases indicate that Justice Murphy, Justice Jackson, and later Justice Rutledge, accepted the Hutcheson ruling. E.g., Allen-Bradley Co. v. Local 3, International Brotherhood of Electrical Workers, 325 U.S. 797 (1945). 
dia and Clayton Acts, read together, had the effect of immunizing peaceful union strikes or boycotts against prosecution under the Sherman Act.

"So long as a union acts in its self-interest and does not combine with non-labor groups, the licit and the illicit . . . are not to be distinguished by any judgment regarding the wisdom or unwisdom, the rightness or wrongness, the selfishness or unselfishness of the end of which the particular union activities are the means." 58

The ruling theoretically may be limited, ${ }^{59}$ but the practical consequence was to make the Sherman Act inapplicable to all combinations of employees regardless of the objective.

The first and indispensable step toward a sound policy for preserving both collective bargaining and a competitive economy is to gain wholehearted acceptance of the proposition that the antitrust laws should not be used to regulate the use of labor's economic weapons. This is not to say that all strikes should be legal, but only that the criteria fpr judging which strikes are tolerable and which are intolerable are not to be found in the body of ideas directed to the preservation of competition. The past shows all too plainly that courts are usually unable to provide acceptable solutions.

The virtue of United States $v$. Hutcheson is that it made this proposition law, even though the judicial tour de force scarcely commands unqualified acceptance. ${ }^{60}$ The fault is that the decision may have been too sweeping. To accept the view that the Sherman Act is not a proper vehicle for evolving a comprehensive law of strikes and picketing does not require one to say that employees may combine to impose restraints on competition which would be unlawful when imposed by employers-for example, fixing the market price. The legality of such restraints should be judged apart from any strike. The strike and its effect upon commerce should be irrelevant except in the sense that a strike should be proscribed as an attempt to impose an unlawful restraint on trade whenever there would be an unlawful restraint if the employer voluntarily acceded to the union's wishes. In the absence of fraud or violence, the Hutcheson case immunized any restraint of trade imposed by a labor union.

In 1941 this was not a serious criticism. The major problem was abuse of the Sherman Act. Unions seldom tried, and had insuffi-

58. 312 U.S. at 232.

59. See text following note 60 infra.

60. Note, 29 Calif. L. Rev. 399 (1941). 
cient power, to affect competition among employers to the detriment of the purchasers of goods and services. Today the situation has changed enough to justify reexamining the latter question.

\section{Union Activities Providing Employers a Sheltered Market}

In recent years labor organizations have initiated or participated in various plans for reducing competition among employers which would constitute per se violations of the Sherman Act if the same restraint were imposed by business firms. The labor contract between the Painters' Union and painting contractors in Peoria, Illinois, is reported to require all contractors to adhere to a minimum price scale. ${ }^{61}$ In 1947, the Atlantic Fisherman's Union refused to discharge vessels until the price of fish was raised to the minimum fixed by union policy. ${ }^{62}$ At least one case reports a union's refusal to furnish men until a contractor joined in a combination to rig bids on a highway construction. ${ }^{63}$

A union may impose restrictions on production in order to maintain market prices. In 1949, the United Mine Workers declared memorial holidays and imposed a three day work week in what one district judge found to be an effort to support the market price of coal. ${ }^{64}$ Perhaps the finding was wrong, but the evidence made it plausible enough to show the possibility of such restrictions.

Exclusion from the market appears to be the most common form of direct union restraint upon competition among business firms. In New York, Local No. 3, IBEW provided local manufacturers a monopoly of the sales of electrical equipment. ${ }^{65}$ More recently a Carpenters' district council refused to handle low cost Canadian shingles because of the competition with local mills. ${ }^{8 \theta}$ Three other forms of exclusion can be found in the construction industry. A Chicago

61. Boston Herald, Nov. 9, 1954, p. 10, col. 1 (lead editorial).

62. Commonwealth v. McHugh, 326 Mass. 249, 93 N.E.2d 751 (1950). See also DeNeri v. Gene Louis, Inc., 174 Misc. 1000, 21 N.Y.S.2d 993 (Sup. Ct 1940), aff'd in this respect, 261 App. Div. 920, 25 N.Y.S.2d 463 (2d Dep't 1941), aff'd in this respect, 288 N.Y. 592, 42 N.E.2d 602 (1942); Manhattan Storage \& Warehouse Co. v. Local 14, Movers \& Warehousemen's Ass'n, Inc., 262 App. Div. 332, 28 N.Y.S.2d 594 (1st Dep't 1941), rev'd on other grounds, 289 N.Y. 82, 43 N.E.2d 820 (1942); cf. Hawaiian Tuna Packers, Ltd. v. International Longshoremen's Union, CIO, 72 F. Supp. 562 (D. Hawaii 1947).

63. Converse v. Highway Construction Co., 107 F.2d 127 (6th Cir. 1939).

64. Penello v. United Mine Workers, 88 F. Supp. 935 (D.D.C. 1950).

65. Allen-Bradley Co. v. Local 3, International Brotherhood of Electrical Workers, 325 U.S. 797 (1945). Similar problems were involved in Anderson-Friberg, Inc. v. Justin R. Clary \& Son, Inc., 98 F. Supp. 75 (S.D.N.Y. 1951); Mayer Bros. Poultry Farms v. Meltzer, 274 App. Div. 169, 80 N.Y.S.2d 874 (1st Dep't 1948).

66. Washington-Oregon Shingle Weavers' Dist. Council, 101 N.L.R.B. 1159 (1952), enforcement granted, 211 F.2d 149 (9th Cir. 1954). 
Roofers' Union is reported to limit the geographical territory in which contractors may take jobs. ${ }^{67}$ Specialty contractors have sometimes been favored by the unions which assert jurisdiction over the specialty trades (e.g., electricians, plumbers, sometimes painters) either by refusing to furnish men to general contractors or by demanding a wage differential. ${ }^{68}$ Also, indictments are now pending charging the Electricians' Union in Chattanooga and the Lathers' and Plasterers' in Chicago with conspiring with business firms to limit construction work to members of specified associations of contractors. ${ }^{69}$ The garment industry, long plagued by the jobber-contractor system, solved the problem under union auspices by limiting the number of contractors who might be employed by a jobber, designating the shops and requiring an equitable distribution of the work. ${ }^{70}$

\section{Labor Disputes}

The Report of the Attorney General's National Committee suggests that these schemes may be crimes under existing law even when the impetus comes from a labor organization seeking to impose the restraint upon reluctant employers. The argument is as follows: The Norris-LaGuardia Act immunizes labor activities only in a case "involving or growing out of a labor dispute." Section 113 (c) defines a labor dispute to include ". . . any controversy concerning terms or conditions of employment. . . ." 71 Union demands which aim at direct commercial restraints do not give rise to a labor dispute because they relate to the sale of commodities or entry into the market and not to conditions of employment. ${ }^{72}$

I disagree. With one exception, ${ }^{73}$ the authorities cited in the Report are irrelevant. Decisions sustaining the power of a state to

67. Boston Herald, Nov. 9, 1954, p. 10, col. 1.

68. The latter practice is certainly rare today, but $I$ encountered a contract only a few years ago in which a local union of painters promised to secure a 25 cents an hour differential from any general contractor to whom it furnished men.

69. United States v. Employing Plasters' Ass'n, 347 U.S. 186 (1954); United States v. Chattanooga Chapter, 116 F. Supp. 509 (E.D. Tenn. 1953). See also Building Contractors Employers Ass'n v. Guglienelli, 128 N.Y.L.J. p. 59, col. 4 (N.Y. Sup. Ct. July 10, 1952); Overland Publishing Co. v. H. S. Crocker Co., 193 Cal. 109, 222 Pac. 812 (1924).

70. Semman, The Needle Trades (1924).

71. 47 Stat. 73 (1932), 29 U.S.C. \$113(c) (1952).

72. REPORT at 298-99.

73. In Hawaiian Tuna Packers, Ltd. v. International Longshoremen's Union, CIO, 72 F. Supp. 562 (D. Hawaii 1947), a district judge upheld a complaint under the Sherman Act against a motion to dismiss, giving the allegation of a demand to fix prices as one of alternative grounds for concluding that there was no "labor dispute." 
outlaw closed shop contracts ${ }^{74}$ cannot fairly be cited as judicial support for the suggestion that the Court may hold there is no "labor dispute" when the union's object is market control. Giboney v. Empire Storage \& Ice Co ${ }^{75}$ went to the Supreme Court upon the constitutional question whether Missouri could punish union conduct which the state court held violative of the state antitrust laws; it is therefore misleading for the Report to imply that the Supreme Court reached an independent conclusion concerning the application of state antitrust laws to the union's activities. ${ }^{76}$ More important is the failure to mention the Court's decision applying the Hutcheson doctrine to an alleged conspiracy to control the market for phonograph records and electrical transcriptions of music. ${ }^{77}$ Nor does the Report take account of the interpretation of labor dispute in Allen-Bradley Co.v. Local 3, IBEW. ${ }^{78}$

In the latter case the facts were as follows: Local No. 3 had jurisdiction over metropolitan New York. Some of its members were employed by manufacturers of electrical equipment and others by construction firms and electrical contractors. In order to increase the volume of work available for union members in the New York factories, Local No. 3 obtained closed shop contracts with the manufacturers and then put pressure on the building contractors to agree not to purchase any equipment not manufactured by members of Local No. 3. A series of agreements soon covered all the manufacturers and all the building contractors in the New York area. One result, of course, was that manufacturers located outside New York-outside the jurisdiction of Local No. 3-could not sell their products for installation in New York City, thus giving a monopoly to the New York manufacturers. Later the arrangement was expanded by setting up a series of agencies composed of representatives of the unions, the manufacturers and contractors for the purpose of price and market control. The New York price of electrical equipment soared so high that New York manufacturers sold their goods in the protected city market at one price and at a far lower price outside. Out-of-state

74. Lincoln Federal Labor Union v. Northwestern Iron \& Metal Co., 335 U.S. 525 (1949) and companion cases.

75. 336 U.S. 490 (1949).

76. The Giboney opinion expressly stated that the Court was ". . . without constitutional authority to modify or upset Missonri's determination that it is in the public interest to make combinations of workers subject to laws designed to keep the channels of trade wholly free and open." Id. at 497. (Emphasis added.) The opinion was written by Mr. Justice Black who had said in Hunt v. Crumboch, 325 U.S. 821, 824-25 (1945), that ". . . Congress in the Sherman Act and the legislation which followed it manifested no purpose to make any kind of refusal to accept personal employment a violation of the Anti-trust laws." (Emphasis added.)

77. United States v. American Federation of Musicians, 318 U.S. 741 (1943).

78. 325 U.S. 797 (1945). 
manufacturers sought an injunction against the union's activities on the ground that there was no "labor dispute" within the meaning of the Norris-LaGuardia Act. Although the Supreme Court granted partial relief on the ground that Local No. 3 had entered into an illicit combination with non-labor groups, it summarily dismissed the contention that there was no "labor dispute" because the union aimed to control the market for electrical equipment. Relegating the point to a footnote, the Court said:

"It has been argued that no labor disputes existed. The argument is untenable. . . . Local No. 3 is a labor union and its spur to action related to wages and working conditions." 79

Later in the opinion Justice Black frankly admitted that this ruling permitted union activities which ". . . may restrain trade in and of themselves . . . both directly and indirectly." 80

Apart from the precedents, it seems unwise to resort to restrictive interpretation of "labor dispute" as a means of cutting down the scope of labor's present immunity from antitrust prosecution. The NorrisLaGuardia Act was the culmination of a long drive based upon the belief that, in a dispute between employers and employees seeking higher wages and better conditions, the lawfulness of concerted activities should depend upon overt acts and not a judgment as to the propriety of their immediate objective. Thus far the federal decisions have been faithful to the purpose. State courts, moved by hard cases, began to hold that strikes for extraordinarily obnoxious objectives did not give rise to a labor dispute within the local anti-injunction laws and, finding no place to stop, ended by reading the full common-law objectives test back into statutes intended to abolish it. ${ }^{81}$ Even if this danger were avoided, the suggested approach would necessarily lead to a new objectives test phrased in the language of management functions as opposed to terms and conditions on which employees may properly bargain, i.e., it would remove from the immunity of the Norris-LaGuardia Act any labor activity aimed at affecting a "management function" whether or not it is directed toward interference by labor with competition in the product market. Government regulation of the subject matter of collective bargaining is of doubtful wisdom even through experts in labor management relations. ${ }^{82}$ The courts have

79. Id. at 807 n.12.

80. Id. at 811 .

81. For illustrative decisions, see Cox, The Role of Law in Labor Disputes, 39 CORNELL L.Q. 592, 596-97 (1954).

82. Cf. Cox \& Dunlop, Regulation of Collective Bargaining by the NLRB, 63 HARv. L. REv. 389 (1950). 
neither the aptitude nor the criteria for reaching sound decisions. Each judicial rubric, moreover, would open the way not only to government prosecution intended to clear the market of artificial restraints, but also to the very private suits for injunctions which the Report elsewhere opposes. ${ }^{83}$

\section{Combination with Non-Labor Groups}

The Committee is on sounder ground when it concludes that a union may be prosecuted under the antitrust laws when it ". . . combines with some non-labor group to affect some direct commercial restraint." 84 The difficulty lies in determining what constitutes such combination, for one can imagine a spectrum of cases ranging from restraints imposed by a union without employer agreement to price fixing schemes concocted by business firms in which the union serves merely as a cloak or enforcement agency. The Report concludes that the Allen-Bradley decision may prohibit ". . . an agreement between one union and one employer requiring conduct whose object is some direct market restraint" even though the contract was ". . . agreed to at union insistence." 85 Once again, I think, the Committee may have misread the Court's decisions. In Allen-Bradley, the district judge held that an effort at direct market control was not a "labor dispute" under the Norris-LaGuardia Act. He therefore enjoined the Local No. 3 from taking any action whatsoever to stop the installation or use of electrical equipment produced by out-of-city manufacturers on the ground that it was not made by members of the union. The circuit court of appeals rejected this theory and reversed the judgment. A seven member majority of the Supreme Court rejected the theory of the district court, but reversed the decree of the circuit court of appeals and ordered a limited injunction. In its view of the facts, Local No. 3 had aided and abetted an illicit combination of manufacturers. ${ }^{86}$ "A business monopoly is no less such because a union participates, and such participation is a violation of the Act." 87 Justice Roberts and Justice Murphy dissented from this analysis of the facts. Both concluded that the union had not in any true sense "aided and abetted" business firms in carrying out a conspiracy to

\section{REPORT at 305 .}

84. Id. at 300 .

85. Id. at $297,298$.

86. "Our problem in this case is therefore a very narrow one-do labor unions violate the Sherman Act when, in order to further their own interests as wage earners, they aid and abet business men to do the precise things which that Act prohibits?" 325 U.S. at 801 .

87. Id. at 811 . 
control the market. Accordingly, Justice Murphy, because he accepted the majority's view of the law, voted to dismiss the complaint. ${ }^{88}$ Justice Roberts, who rejected the majority's legal conclusions, disapproved the limitations on the injunction ordered by the Court. ${ }^{89}$ In all of this, I can find no intimation that the Court might permit “. . . antitrust prohibition of an agreement between one union and one employer requiring conduct whose object is some direct market restraint." 90 In such a case there is no illicit combination of business firms to aid or abet.

Nor is there reason to doubt the soundness of the majority's assumption that a union does not violate the antitrust laws by negotiating parallel restrictive agreements with competing business firms. ${ }^{91}$ In this situation, there may be sufficient evidence of combination among the employers if each knows the others' action, ${ }^{92}$ but the law could not tolerate the paradox of sanctioning strikes for uniform agreements while proscribing them as treaties of peace. Accordingly, courts and commentators have interpreted Allen-Bradley as holding that the negotiation of parallel collective agreements effecting market control, when sponsored by the union, does not violate the Sherman Act. ${ }^{93}$

Beyond this point prediction becomes sheer speculation. An association of employers which bargains as a unit ought to have the same privilege of surrendering to union demands as a series of individual firms, yet such an arrangement plainly does involve a combination of business firms. It is vulnerable under the Allen-Bradley ruling, therefore, unless that decision means only that ". . . benefits to organized labor cannot be utilized as a cat's-paw to pull employers' chestnuts out of the antitrust fires." 94 This too is hardly a satisfactory standard, even though the best, and one wonders whether an administrable line can be drawn so long as unions are free to impose the very same market restraints that are criminal for employers.

88. Id. at $820-21$.

89. Id. at $813-20$.

90. Report at 297. The Committee seems to have reached this conclusion by taking Justice Roberts' view of the facts and then interpreting the decision of those who rejected his view as a holding limited to the issues his view would have presented. Justice Roberts suffered from no such illusion as to the meaning of the decision. See 325 U.S. at 819.

91. Id. at 809 .

92. The doctrine of "conscious parallelism" has not yet been applied in labor cases. Its development in business cases is discussed in the REPORT at 36-42.

93. E.g., Douds v. Local 28, Sheet Metal Workers Int'l Ass'n, 101 F. Supp. 970 (E.D.N.Y. 1952) ; Dodd, The Supreme Court and Organized Labor, 1941-1945, 58 HARV. L. REv. 1018, 1051 (1945).

94. United States v. Women's Sportswear Ass'n, 336 U.S. 460, 464 (1949). 


\section{The Issue of Public Policy}

A combination which fixes prices, limits production or deteriorates quality in the market in which the employer sells his goods, or which limits access to that market except as a weapon in some other labor dispute, appears to have the same effect on the consumer regardless of whether it is imposed by businessmen, labor organizations or jointly by both. Such a combination of business firms is a per se violation of the antitrust laws. From the standpoint of public policy, therefore, the chief question would seem to be whether we should treat the ultimate aim of benefiting workers as sufficient justification when a union acts, although we do not place so high a value on increasing profits. Surely the two are not the same; and the interest in raising workers' standards may well have been sufficient when wages were low and unions were weak. The passage of time, however, has increased their power to make restraints effective and the improvement in workers' living standards has made the plea of justification so much less persuasive that $I$ am inclined to think that the justification is no longer sufficient. It follows that the present immunity of labor unions should be cut down by legislation if the theoretical abuses have practical importance and can be handled without either interfering with legitimate organizational and bargaining tactics or using the judicial process to make labor policy. ${ }^{95}$

Although we must postpone discussion of the problems of drafting satisfactory legislation until all the substantive issues have been covered, it is important to emphasize here that there is no reliable information on the extent or economic importance of union efforts to shelter employers from competition in the product market. Instances have come to light which shock the conscience. They are numerous enough to create the suspicion that many more may lie beneath the surface, but they may be local, ineffective or temporary. A careful factual inquiry, backed by power to elicit information, seems essential to reaching firm conclusions on the policy question.

\section{Featherbeding and Opposition to Technological Change}

Proposals to subject union activities to the antitrust laws usually lump "featherbedding" and make-work devices together with pricefixing, limitations on production and similar methods of product market

95. This analysis ignores one debatable issue. There is evidence that per se restraints are sometimes beneficient during an economic downswing because they stabilize the market against destructive competition. The coal and garment industries are notable examples. If there were space to debate the point, I might acknowledge the case for exceptions but argue the need for public supervision before any were admitted. 
control. The classification is not strictly accurate. Many instances of featherbedding have no relation to the preservation of market competition-for example, setting "bogus type," employing musicians to stand by or play introductions for the performances of a travelling band or carrying a swamper as an idle passenger on a bulldozer clearing a construction site. Often these practices waste skilled manpower, our most precious resource. They offend moral sensibilities by compelling payment for work not done. But their wrongness neither makes them part of the problem of preserving business competition nor warrants the conclusion that the remedy is a blunt legal prohibition.

Other forms of featherbedding plainly do restrain competition among business firms. When carpenters or painters refused to install prefabricated kitchen cabinets, they not only suppressed competition between men and machines, but they protected old line lumber dealers and contractors against new business methods. ${ }^{96}$ The same consequences follow wherever there is a refusal to use or install new products. ${ }^{97}$ Despite some distinctive aspects, I am inclined also to place in this category those inhibitions on new machinery or methods of production which are typified by union opposition to spray guns, readymixed concrete and recorded music. Where there is resistance to new products, moreover, if not in other cases, the union is seeking to control the product market just as directly as where it fixes prices or excludes out-of-town competitors from local work.

Yet there is at least one fundamental difference. Workers' opposition to new products and technological change stems from an ancient and well-founded fear of loss of job opportunities. Centuries ago, unorganized workers rioted when their handicraft skills were threatened by machinery. ${ }^{98}$ An employer decides whether and when to install new machinery reducing the cost of manufacture with one eye on the cost he must recover if he junks his present equipment. He does not throw away his first capital investment. Is there not an equally good case for taking into account the costs to employees in the frictional unemployment and loss of skill which result from labor-

96. United States v. Painters District Council No. 14, 44 F.2d 58 (N.D. IIl. 1930), aff'd, 284 U.S. 582 (1931).

97. See, e.g., United States v. Carrozzo, 37 F. Supp. 191 (N.D. Ill.), aff'd, 313 U.S. 539 (1941) (ready mixed concrete); Joliet Contractors Ass'n v. NLRB, 202 F.2d 606 (7th Cir. 1953) (pre-glazed window sash); Gunderheimer's, Inc. v. Bakery \& Confectionery Workers', 119 F.2d 205 (D.C. Cir. 1941) (mass produced pastries); Douds v. Local 28, Sheet Metal Workers Int'l Ass'n, 101 F. Supp. 273 (E.D.N.Y. 1952) (prefabricated radiator enclosures); Anderson-Friberg Co. v. Justin R. Clary Co., 98 F. Supp. 75 (S.D.N.Y. 1951) (quarry finished grave stones).

98. Aaron, Govermmental Restraints on Featherbedding, 5 Stan. L. Rev. 680 (1953), is an excellent survey of the problem. 
saving devices? Make-work is not the way to solve the problem; nor is the answer in preventing technological change. Probably the solution lies in a combining of wise collective bargaining with improved social legislation. The government can do much to alleviate the insecurity which breeds opposition to laborsaving products and machinery by providing adequate unemployment compensation, improving its job referral services and sponsoring retraining programs. Labor and management can meet the needs of particular industries and specific firms by bargaining about the timing of technological changes, about transfers and job preferences, the costs and availability of retraining, and severance pay or other measures for assisting workers during frictional unemployment.

In my opinion, therefore, the chief objection to legislation outlawing featherbedding combinations is that it seeks to repress the symptom without curing the disease. Most of the measures proposed not only offer no affirmative assistance, but even prevent workers from using their bargaining power to mitigate their loss through severance pay or other compensation.

A second objection is the want of any satisfactory answer to the question: Who should decide what constitutes featherbedding? The philosophy of collective bargaining denies the right of an employer to decide by fiat. The only alternative, except for collective bargaining, is to give the task to a court or administrative agency. Congress rejected this solution in the passage of the Taft-Hartley Act because Senator Taft opposed so much government regulation. ${ }^{99}$

Third, any legal restriction would be too easy to evade. Suppose that it were declared unlawful to combine to compel employers to forego the use of paint rollers or spray guns. At the next contract negotiations, the Painters' Local would demand a new wage scale, viz.

$\begin{array}{ll}\text { Brush } & \$ 1.80 \\ \text { Roller } & \$ 2.50 \\ \text { Spray } & \$ 3.50\end{array}$

Are the latter rates penalties intended to prevent the use of laborsaving devices by making them uneconomical or do they simply reflect legitimate bargaining over the employees' claim to higher wages for increased productivity? To provide machinery for the adjudication of such questions would press the government far down the road of regulating wage rates. To prohibit concerted activities for the announced purpose of preventing technological change while permitting such easy

99. 93 Cong. REc. 6441, 6443, 6859 (1947). 
evasion would produce only contempt for the statute and undermine the force of law.

Perhaps anti-featherbedding legislation would have to be enacted despite these faults if there were proof that the restrictions were seriously damaging our economy. But few economists would assert this with conviction, and, from a layman's observation, I suspect that the offense to our moral sensibilities greatly exceeds its economic importance. New products and new machinery break through the barriers. Ready-mix concrete rolls down the highways. Does any parent notice a shortage of juke boxes or disc jockeys?

\section{The Effect of Collective Bargaining on Competition IN THE Product Market}

The bargaining power achieved by labor organizations since enactment of the Wagner Act has greatly increased the potential consequences of lessening competition in the labor market. Space precludes attempting to analyze them in detail; besides, the author lacks the economic competence. This article would be incomplete, however, without some discussion of the resulting problems which have been debated in the legislative forum.

\section{Industry-Wide Bargaining}

There are few industries where bargaining is carried on between one union representing all the employees and a formal or informal association of all the employers. Market-wide bargaining is more common although its precise form varies with the characteristics of the relevant labor and product markets. Any evils in industry-wide bargaining occur on a lesser scale when bargaining is market-wide.

In 1947, the House of Representatives passed ${ }^{100}$ but the Conference Report rejected ${ }^{101}$ amendments to the proposed Labor-Management Relations Act which were publicized as measures to outlaw industry-wide bargaining. Similar bills were introduced in later congresses without such wide support. ${ }^{102}$

A great measure of the popular support for these proposals apparently stemmed from the belief that they would also deal with the ". . . industry-wide strikes that paralyze our economy and that im-

100. H.R. 3020, 80th Cong., 1st Sess. (1947).

101. H.R. REp. No. 510, 80th Cong., 1st Sess. 36, 59 (1947).

102. E.g., H.R. 8449, 82d Cong., 2d Sess. (1952), by Mr. Gwinn; H.R. 2545, 83d Cong., 1st Sess. (1953), by Mr. Lucas. 
peril the health and safety of our people." 103 A prohibition against striking more than a specified percentage of the supply of essential goods and services might be feasible in the bituminous coal industry and one or two others. The measure would not be feasible for utilities where there is a single source of supply or for strikes against firms like American Locomotive Co. whose output was a critical factor in atomic development. ${ }^{104}$ In any event, such legislation should be considered with alternative measures for handling public emergency disputes rather than in the context of laws concerned with fostering market rivalry.

Another argument against industry-wide bargaining is that it reduces price competition. When each employer knows that all his competitors in the product market will grant similar increases in wages and fringe benefits, each may lose incentive to resist the union's demands because all will have to make the same price increase. The result, the argument runs, is not only a lessening of competition but also an inflation of wages and prices which is against the public interest.

The trade union philosophy first expounded by the Webbs has consistently held that a union cannot be effective unless organization is coextensive with the market and eliminates price competition based on differences in labor standards. ${ }^{105}$ Bargaining in a single, multiemployer unit is by no means essential; when the union has organized the major firms in the relevant market, each has almost the same assurance of substantially uniform increases in labor standards as when the bargaining takes place in a single formalized unit. For example, there is no formal, multi-employer bargaining in the basic steel industry, which is often cited as the prime illustration of the consequences of permitting a labor union to take wages out of competition. In many industries-perhaps all-the formation of an employer association may well enable firms to resist wage increases which the union could otherwise exact by threatening to shut down one firm at a time while competitors fill the market. The significance of this countervailing power in retail and service industries characterized by small firms is attested by the frequency with which unions try to break up the association by resorting to whipsawing when association-wide negotiations reach an impasse. ${ }^{108}$

103. H.R. Rep. No. 245, 80th Cong., 1st Sess. 8-9 (1947).

104. See United States v. American Locomotive Co., 109 F. Supp. 78 (W.D.N.Y. 1952), aff'd sub nom. United States v. United Steelworkers, CIO, 202 F.2d $13 \dot{2}$ (2d Cir. 1953).

105. Sidney Werb \& Beatrice Webb, Industrial Democracy (1902).

106. See, e.g., Morand Bros. Beverage Co., 91 N.L.R.B. 409 (1950), remanded, 190 F.2d 576 (7th Cir. 1951), on remand, 99 N.L.R.B. 1448 (1952), enforced, 204 F.2d 529 (7th Cir. 1953). 
The logical thrust of the wage-price argument was reflected in the bills debated during 1947 . Their real aim was to destroy industrywide or market-wide union organization by forbidding a union to represent the employees of two or more competing employers or to coordinate its bargaining with other locals. We should examine on its merits the question whether it would be wise thus to fragmentize the labor movement, but for the moment I insist only that it be recognized that the evil-if it be an evil-is industry-wide (more accurately marketwide) unionization and not industry-wide bargaining.

\section{Industry-Wide Unionization}

In weighing the effects of industry-wide (or market-wide) unionization upon the likelihood of preserving the kind of competition to which we look for protection against injuries to consumer interests, one must take into account several practical qualifications limiting the wage-price theory developed from a simple model.

Character of the Industry.-A casual observer is struck by the fact that the international unions which impose the most uniform wage patterns upon competing employers are usually found in two environments. One group is the oligopolistic industries-basic steel, meatpacking and rubber-where there appears to be little competition in basic prices. In these situations the character of the industry may be the cause of price and wage uniformity, or the price uniformity which antedates collective bargaining may have led to following-the-leader in wage negotiations. Union policies could do scant harm by impairing a non-existent form of competition.

The other environment is characterized by competition so intense as to raise serious problems during any slackening of business activity. The bituminous coal and garment industries are the best examples. In the garment industry, competition was formerly so intense, and wages were so large a part of total cost, that individual firms were driven to hire at rates which the management knew to be inadequate, and a union could not exist without market-wide organization. The history of the coal industry is similar. No one seriously suggests that putting wage scales back into competition would be in the public interest in this environment.

Wages, Labor Costs, and Prices.-Under a simple piecework system, a uniform increase in the wage rates paid by competing firms results in a uniform increase in labor costs and would require a uniform 
price increase unless absorbed or offset by other savings. Reality departs from the model. Changes in hourly rates do not have the same uniform effect on total costs because of variations in the ratio of labor costs to total costs, in the efficiency of plant, equipment and management and, at least theoretically, in the productivity of labor. The variation would be even wider in an industry where some workers receive piece rates, some are paid hourly rates and still others work under bonus systems. Furthermore, management has shown amazing skill in reducing the cost of wage increases through new machinery, improved engineering and like economies. In short, industry-wide unionization does not automatically eliminate labor costs from competition.

Competition and Wage Adjustments.-There is little evidence that breaking up industry-wide unions like the United Steelworkers and United Automobile Workers would lessen the pressure for wage increases or stiffen management against concessions. The economic studies have limited scope, but the best indicates that wages in industries where bargaining is national or regional have not risen more than in manufacturing generally. ${ }^{107}$ Conversely, there is no evidence that management has been able to drive tougher bargains in the major industries in which there are two or more unions claiming jurisdiction -for example, airframe, meatpacking, aluminum and northwest lumber. ${ }^{108}$ While this data is obviously incomplete, it casts considerable doubt on the opposing theory.

Perhaps the fault is that the theory exaggerates the extent to which wage setting is influenced by price competition among firms in the same industry. Competition often crosses conventional lines of demarcation. To use a homely illustration, commercial laundries are not only in competition with each other but with launderomats, home washing machines and even the old fashioned scrubbing board, not to mention the initially expensive but easily washed dacron shirts. Similarly it is far from clear that the wage leaders give as much weight to competition in their bargaining as to the effect of wage adjustments on their long range planning and the development of the national economy. Among smaller firms, the influence of cost comparisons is watered down by local labor market considerations, traditional differentials,

107. Lester \& Robie, WAges Under National aNd Regronal Collective BARGAINING (1946).

108. The bitter interunion rivalry between International Union of Electrical, Radio and Machine Workers, CIO, and United Electrical, Radio and Machine Workers seems to have enabled General Electric Co. to play one off against the other and thereby gain advantage in bargaining. 
cross-industry occupational comparisons, etc.; and the international union which must think of an entire industry, including the marginal firms, not infrequently exercises a moderating influence on the wage demands of local leaders.

There can be no quantitative measurement of the net effect of these qualifications on the argument that industry-wide unionization unduly limits competition as a factor in keeping down labor costs; but they add at least a grain of salt. The nub of the matter, I suspect, is that the problem is not really one of market competition in the usual sense. The antitrust tradition opposes price-fixing, limitations on production and the allocation of customers because of the dangers of lazy management and excessive profits. Limiting access to the market produces these consequences and also curtails economic opportunity. Market-wide unionization does not seriously impair this kind of competition or produce these consequences. On the other hand, the qualifications noted above scarcely disprove the rather plausible assertion that wages and prices are bound to rise when large scale unions annually present the bulk of employers with demands for increased benefits which will tend to increase labor costs, for the uniform upward trend gives employers considerable assurance of ability to raise prices if necessary.

So stated the issue is not one of competition but inflation. Possibly we must choose some two of the three ideals of strong labor unions and free bargaining, full employment and a stable price level. ${ }^{109}$ If so, the reader can make his own selection. I add only the suggestion that he may first wish to ask whether a choice would seem necessary in the realm of labor relations policy if we had not recently lived through a period marked by other causes of inflation.

\section{LEGISLATIVE REMEDIES}

Legislation overruling the Hutcheson doctrine and subjecting labor unions to the Sherman Act in general terms would require the courts to decide the four major issues of policy which serve as the central theme of this article:

(1) Does the restraint of interstate transportation by a strike or boycott bring a case under the Sherman Act so that an offense is made out if the court deems the union's objection "unreasonable" or "unlawful"?

(2) Is it a violation for a union to provide employers with a sheltered market by strikes or collective bargaining agree-

109. Slichter, How Bad is Inflation, Harpers, Aug. 1952, p. 53. 
ments fixing prices, limiting production or restricting access to the market, etc.?

(3) Does the Sherman Act forbid concerted union activities preventing the introduction of new products or new machines?

(4) How far does the act apply to activities in the labor marketsuch as organizational strikes and boycotts or bargaining about wages and hours-where the object or consequence is to affect competition in the sale of goods?

The second question requires an affirmative answer. The others are open to various degrees of doubt and unless the answers were all affirmative, the courts would also have to draw the lines of distinction. Surely no one will deny either the duty of Congress to decide such basic issues or the folly of opening up so vast a field for litigation. Furthermore, unless the substantive purpose is to proscribe as many union activities as possible, firmer safeguards should be incorporated for those deemed legitimate.

In my opinion, a case can be made out for applying the Sherman Act only to those union imposed restraints which fall in the category discussed previously in this article-tampering with the product market for the sake of sheltering employers from competition otherwise than by organizing the employees of competitors and raising their labor standards. Even here the issue turns on balancing the practical need for legislation-which has never been demonstrated-against the diffculties in writing prohibitions which would neither charge the courts with making labor policy nor cast doubt or organizational activities and collective bargaining.

One who starts from this premise will not be satisfied with past proposals for applying the Sherman Act to labor unions. In 1952, the House of Delegates of the American Bar Association approved a bill to amend the Sherman Act which recited in a preamble that

". . . the field of activity which this bill is intended to regulate is that defined . . . in the case of Apex Hosiery Co. v. Leader . . as 'commercial competition'. . . ."

and then enacted that section 1

“. . . shall apply in respect of labor organizations, the officers and members thereof, insofar as they engage in combinations, contracts, or conspiracies in restraint of trade or commerce . . . where the purpose or effect . . . is to restrain commercial competition. . ." 110 
The recommendation is too vague because the Apex case left too many questions unsettled. ${ }^{111}$ An organizing strike might be held unlawful if the union were conscious of the competition of non-union goods. The emphasis on "purpose or effect" suggests that section 1 might reach not only restraints in our second category, but also concerted activities or negotiated agreements in the fourth.

Another approach is typified by a bill which Congressman Gwinn introduced at the $82 \mathrm{~d}$ Congress. ${ }^{112}$ The pertinent provision declared that section 1 of the Sherman Act should apply to combinations of labor organizations or their members

". . where an object or necessary effect is to . . . control or fix prices that employers may charge for their goods or services; or limit the amount of goods any employer may produce, sell, or distribute, or the amount of any services any employer may render; or limit the area in which, or the persons to whom, any employer may sell or distribute goods or render services, or from whom any employer may acquire goods or services; or limit the number of employers who may engage in any particular business, or for whom members of any such labor organization will perform work. ..." 113

The language blurs the critical distinctions. Price-fixing schemes can be readily identified once direct regulation of product prices is differentiated from strikes or bargains in the labor market which may affect or even govern price movements through the establishment of uniform labor standards. Perhaps the Gwinn bill incorporates this distinction with reference to bargaining, but it is less clear that it would not revive the Second Coronado and Alco-Zander cases. ${ }^{114}$

The Gwinn bill appears to ignore the more difficult but nonetheless critical distinction between the familiar goals of shorter hours or plans for spreading available work, on the one hand, and, on the other hand, limitations on production motivated by a desire to protect weak firms or support market price. When UMW forced the bituminous coal mines to observe a three day week for several months, was the union engaged in an effort to keep marginal producers afloat or to steady coal prices by restricting and allocating production-both direct efforts at

111. See text at pp. 263-64 supra.

112. H.R. 8449, 82d Cong., 2d Sess. $§ 2(3)$ (1952). The bill also covered other subjects such as "industry-wide bargaining." Similar provisions were contained in the House version of the Taft-Hartley Act. H.R. 3020, 80th Cong., 1st Sess. $\$ 301$ (1947).

113. Ibid.

114. See text at pp. 260-61, 264 supra. 
market control - or in spreading the available work among the normal labor force so that each worker would have some income-a familiar union measure-while at the same time "softening up" the operators for contract negotiations? Neither test of "object" nor "necessary effect" gives a satisfactory answer to the question. Even if his dominant motive was to spread the available work, John L. Lewis would not be blind to the other consequences or leave them out of his calculations. Were they therefore "an object" of the combination? If not, were they a "necessary effect"?

The ill will engendered by UMW strikes should not be allowed to obscure the fact that a beneficient limitation on hours of work will affect production or sales whenever the employer is short of working space or capital equipment or has difficulty in introducing new shifts. Some line must be drawn unless the law is to interfere with normal collective bargaining about the length of the work week. Possibly the best solution is to deal with the clear abuses by outlawing only restrictions phrased in terms of the volume, leaving closer cases untouched in order to avoid the interference.

The most difficult problems concerned exclusion from the market. The Allen-Bradley case illustrates the kind of restriction on competition which the antitrust laws should forbid, but a slight change in the facts would convert it into a problem involving only labor policy. Local No. 3's refusal to install goods not made by its own members erected an objectionable trade barrier because the limitation on its territorial jurisdiction excluded goods not made in New York. If Local No. 3 dropped this limitation and agreed to install equipment made by any local of its union whether in New York or not, a refusal to handle goods made by others would have amounted only to a secondary boycott for organizational purposes. Such boycotts may be highly objectionable-especially where directed at goods made by a competing union rather than non-union goods-but nothing is gained and much may be lost by transferring the debate over secondary boycotts from the field of labor relations into the context of the antitrust laws. The Gwinn bill would bring all secondary boycotts under the Sherman Act. The Report of the Attorney General's National Committee seems to share the same purpose. ${ }^{115}$ Secondary boycotts in aid of organizing campaigns and strikes for higher labor standards do not significantly hamper our efforts to maintain a competitive economy. Consequently, it would seem wiser to confine any amendment to the antitrust laws to situations where a trader is excluded from the market

115. REPORT at 302-03. 
without assurance of readmission upon the union's prevailing in some controversy over the association or representation of employees or their conditions of employment.

Even this clumsy standard leaves doubtful cases. The 1949 contract between International Association of Machinists and the St. Louis breweries stipulated that when the repair or replacement of machinery was necessary, the work would be done with brewery employees or by contractors who had collective bargaining contracts with IAM. ${ }^{116}$ Pipe manufacturers whose employees belong to the Steelworkers often complain of agreements between plumbing contractors and the United Association of Journeyman Plumbers and Steamfitters committing the contractors to use only pipe manufactured in shops which bargain with the United Association. In some instances these agreements may be parts of a current drive to expand union membership, but when organizational activity has slackened off and there is no real chance of a change in employee sentiment, the stipulations look suspiciously like an effort to provide a sheltered market.

It would be captious to insist that legislation should be held up, despite a demonstrated need, until language was developed covering every conceivable illustration. Borderline cases can be left to the courts with the assurance that our labor unions will remain strong and our economy competitive regardless of the outcome. On the other hand, the experience of organized labor under the Sherman Act seems adequate justification for insisting that only the truly borderline cases be left for judicial decision. At the very least, the language of any amendment should take account of the basic distinctions and indicate how the courts are to regard each of the five categories of restraints outlined in this paper.

Perhaps words are not adequate to the task. The bills which have gained some measure of support give little encouragement, but the true explanation of their ambiguities may be that the draftsmen started with a different premise. Taking my premise, however, it might be a preferable technique to guide the courts through an explicit declaration of legislative policy couched in terms of the critical distinctions. The primary offense should be entering into agreements with employers fixing prices, limiting production or cutting off access to a market. This would focus attention on the gist of the antitrust violation and avoid confusion with matters of labor policy. Strikes to compel the execution of an illicit contract would then fall into place as illegal attempts or conspiracies to bring about commission of the major of-

116. See Dist. No. 9, Int'l Ass'n of Machinists, 101 N.I.R.B. 346, 349 (1952). 
fense. Having cast stones rather widely, I append in the margin a rough target prepared along the lines of this suggestion. ${ }^{117}$

117. Section 1. The Congress finds-

(a) It is the policy of Congress, set forth in the Labor-Management Relations Act of 1947, to promote and encourage collective bargaining concerning wages, hours and other terms and conditions of employment and, to that end, to safeguard the right of employees to form, join and assist labor organizations, to bargain collectively through representatives of their own choosing and to engage in concerted activities for the purposes of organization, collective bargaining and other mutual aid and protection.

(b) It is also the policy of Congress set forth in the antitrust laws to prevent monopoly and promote product market competition among employers in the sale of goods and services.

(c) Labor organizations, acting alone and in combination with employers, have sometimes gone outside the sphere of organization and collective bargaining and have fixed prices, limited production, allocated territory or sales among employers, and imposed other like restraints on competition among employers in the product market, all being of a kind which would violate the antitrust laws if imposed by business groups.

(d) The policy of this Act is to prevent and punish such restraints without regulating the freedom of employees, labor organizations and their members to engage in strikes, boycotts or other concerted activities for the purposes of organization and collective bargaining or the negotiation and administration of agreements relating to the wages and other compensation of employees, their hours and working conditions, or their tenure and security of employment.

Section 2. It shall be unlawful for a labor organization or its officers or members to enter into any contract or agreement affecting interstate commerce which-

(a) fixes prices, or

(b) limits the volume of production or sales (otherwise than by establishing hours of employment, overtime premiums, work loads, work standards, or measures for sharing available work), or

(c) restricts the number or kind of employers or other persons who may engage in any particular kind of business activity or for whom members of a labor organization will work, or the area in which an employer or other person may sell goods or services, or the persons with whom an employer may do business, or

(d) otherwise, but in like manner, limits access to a market other than a labor market by employers and other persons engaged in business activity.

Section 3. It shall be unlawful for a labor organization or its members or employees to engage in a strike, boycott or other concerted activities where an object thereof is to compel any employer to enter into a contract or agreement prohibited by Section 2, provided that nothing contained in this Act shall be deemed to prohibit a labor organization from excluding an employer from the market as an incident of a current dispute with such employer concerning the association or representation of employees or their terms or conditions of employment, regardless of whether the disputants stand in the proximate relation of employer and employee. 